\title{
Land Use Change and Livelihoods in the Plantation Nouvelle de Ngambe Tikar (Pnnt) Community Forest, Center Region of Cameroon
}

\author{
Nghobuoche Frankline ${ }^{1,}$, , Tsafack Ngoufo Serge ${ }^{1}$, Akoni Innocent Ngwainbi ${ }^{2}$, \\ Godwill Tobouah Nyanchi ${ }^{1}$, Tieminie Robinson ${ }^{3}$ \\ ${ }^{1}$ Department of Geography, Faculty of Arts, Letters and Social Sciences, University of Yaoundé 1, Yaounde, Cameroon \\ ${ }^{2}$ Graduate School of Government, Business and Entrepreneurship, Department of Public Administration, Yonsei University, Wonju, South \\ Korea \\ ${ }^{3}$ Department of Forestry, Faculty of Agronomy and Agricultural Sciences, University of Dschang, Dschang, Cameroon
}

\section{Email address:}

nghobuochefrank@gmail.com (N. Frankline), tsafackngoufo@hotmail.fr (T. N. Serge), alljusticeyuh@gmail.com (A. I. Ngwainbi), goddy288@yahoo.com (G. T. Nyanchi), tieminier@gmail.com (T. Robinson)

${ }^{*}$ Corresponding author

\section{To cite this article:}

Nghobuoche Frankline, Tsafack Ngoufo Serge, Akoni Innocent Ngwainbi, Godwill Tobouah Nyanchi, Tieminie Robinson. Land Use Change and Livelihoods in the Plantation Nouvelle de Ngambe Tikar (Pnnt) Community Forest, Center Region of Cameroon. American Journal of Biological and Environmental Statistics. Vol. 6, No. 3, 2020, pp. 31-42. doi: 10.11648/j.ajbes.20200603.11

Received: July 3, 2020; Accepted: July 17, 2020; Published: August 20, 2020

\begin{abstract}
This study aims at identifying changes in land use composition, structure and distribution in PNNT Community Forest in the Center Region of Cameroon, from 2001 to 2020 and to investigate the impact of the search for livelihoods on the change. Obtained results revealed that there are four major land uses in the PNNT community forest; Moist evergreen forest, degraded forest, savanna and bare soils. Land use change analysis indicated that, the surface area covered by moist evergreen forest reduced by $5 \%$ while that of savanna reduced by $15.4 \%$ from 2001 to 2020 . The findings indicated that 255,87 hectares of moist evergreen forest was lost between 2001 and 2020; an average of 13.47 hectares per year. The surface area of savanna reduced significantly from 1919.28 hectares in 2001, 1658.39 hectares in 2011 and to 1124,91 hectares in 2020. Results further revealed a substantial increase in the surface area of bare soil by $17 \%$ and degraded forest by $3.4 \%$ over 19 years. The total surface area of degraded forest increased by 174.4 hectares from 2001 to 2020 . The land use with the most significant positive change was bare soils which increased from 396.61 hectares in 2001 to 1272.45 in 2020; a global increase of 875.84 hectares. Agricultural expansion, increased logging and harvesting of non-timber forest were identified as drivers of land use change in the community forest.
\end{abstract}

Keywords: Land Use Change, Livelihoods, Community Forest, Plantation Nouvelle De Ngambe Tikar, Cameroon

\section{Introduction}

On a global scale, anthropogenic activities such as agriculture, industry and transport underlined with various socio-economic, political and institutional factors have resulted in land use changes [1]. Land use change driven by human activities and natural factors resulted in the global loss of native biodiversity and the alteration of ecological processes and services across different ecosystems [2]. In some parts of Africa, the expansion of agriculture influenced by rapid population growth has been recognized as a primary driver of land use change [3]. Most land use change is a direct result of people's responses to economic opportunities as mediated by institutional factors $[4,5]$ and the land use changes include changes from forest to farmland which is typically accompanied by deforestation. About $20 \%$ of the global population depends on forests for employment, forest products livelihoods and incomes [5-8]. Moreover, about $83 \%$ of the extreme poor living in developing countries depend on forest resources for all or part of their livelihoods [9, 8]. In Cameroon, the forest sector contributes to about $2.8 \%$ of the GDP 
(US\$695.3 million) and provides direct employment to 22,000 people $[10,8]$. It is estimated that the number of people employed temporally or permanently in the sector at more than $2,478,880$. Community forest refers to forests in which local communities use and have some degree of formal responsibility and authority for forest management. In Cameroon, community forest also aims at providing rural communities with income generating mechanisms for equitable socio-economic development of their communities, therefore alleviating poverty [11-14]. Non-timber forests products (NTFPs) play a key role in the daily life of millions of people living in the rural areas of Cameroon [8]. The collection and sales of NTFPs constitute an important source of food, cash $[15,16,8]$, and employment for rural dwellers. This activity creates at least 283,000 direct and indirect jobs at various levels of the NTFPs value chain $[16,8]$. Since the late 1980s, community forests (CFs) have emerged in a growing number of developing countries, largely because of failing centralized forest policy [13]. Currently, approximately $18 \%$ of global forest is under community ownership or administration $[17,13]$. Most people living in community forests are dependent on the forest to sustain their livelihood. Therefore, several activities are undertaken by local populations to satisfy their daily needs, as well as to generate revenues through industrial logging, NTFPs collection, subsistence agriculture, agroforestry, hunting, fishing and charcoal production [18, 19, 13].

The study therefore aim at exploring the relationship between land use change and livelihood activities within the PNNT community forest. In addition examine the distribution of the land uses within the community forest; compare land use change from 2001-2020; and finally discuss the livelihood activities within the community forest and influence on land use change.

\subsection{Legal Framework of Community Forest in Cameroon}

Community forest has emerged as one of the keys to the involvement of local actors in forest conservation and sustainable management. It aims at improving the living conditions of local populations while ensuring the sustainability of the resource. In Cameroon, it is governed by forestry Law $\mathrm{N}^{\circ} 94 / 01$ of 20 January 1994 on the forest, wildlife and fisheries regime and Decree $\mathrm{N}^{\circ}$ 95-531 of 23 august 1995 laying down modalities for the implementation of the forest regime [20].

This decree defines community forests (CFs) as a portion of non-permanent forest domain (DFNP) that the state assigns to a community at the request of the community and is managed based on an agreement signed by both partners. The first of such agreement was signed in 1997 and since then the number of CFs applications has steadily increased. Historically, the East region is number one in terms of CFs created and operating within the country.

The decree of application states that forest situated adjacent to one or more communities or villages in which they carry out many activities can be designated as community forest (Art 27-2). The community forest certificate should be signed by the Ministry of Forestry and Wildlife (MINFOF) offering free technical assistance to the villages concerned.

The forest susceptible to be attributed to the communities as their property (Art 27-3) must not have a surface area of less than 5000 hectares. The community forest is under a management convention between the communities and the administration for a period of 25 years renewable. A simple management plan has to be established and to be revised after 5 years [22].

The process of creation and management of community forest is based on two conventions:

Temporal management convention with application for the attribution of community forest. This convention hands over the right of the community forest to the villages for a maximum non-renewable period of 2 years.

Final management convention, a minimum renewable period of 25 years.

The exploitation of community forest is carried out by communities in place or sub-contracted as a Sale of Standing Order (SSO). It has to be exploited using an exploitation permit or a personal authorization to cut (Art 95-1) with prior accord from forest administrators in place.

Regular measures for the attribution and management of CFs include:

1. Ordinance $\mathrm{N}^{\circ} 0677 / \mathrm{LC} / \mathrm{MINEF} / \mathrm{DF} / \mathrm{CFC}$ of 23 February 2001 which limits the industrial exploitation of community forest.

2. Ordinance $\mathrm{N}^{\circ} 0518 / \mathrm{MINEF} / \mathrm{CAB}$ of 21 of December 2001 that put in place modalities of application of rights of adjacent communities of some forest space.

3. Decision $\mathrm{N}^{\circ} 1985 / \mathrm{D} / \mathrm{MINEF} / \mathrm{SG} / \mathrm{DF} / \mathrm{CFC}$ of 26 June 2002 that specify modalities of operation of community forest in the context of the implementation of simple management plan.

4. Decision $\mathrm{N}^{\circ}$ 0098/D/MINFOF/SG/DF/SDFC of 12 February 2009 on the adoption of documents entitled "manual on the attribution processes and management norms of community forest".

Table 1. Evolution of community forest in Cameroon.

\begin{tabular}{lllll}
\hline Year & $\begin{array}{l}\text { Application for } \\
\text { community forest }\end{array}$ & $\begin{array}{l}\text { Temporal } \\
\text { convention }\end{array}$ & $\begin{array}{l}\text { Final } \\
\text { convention }\end{array}$ & $\begin{array}{l}\text { Active community } \\
\text { forest }\end{array}$ \\
\hline 2010 & 480 & 0 & 187 & 140 \\
2011 & 490 & 35 & 200 & 140 \\
2012 & 510 & 50 & 230 & 150 \\
2013 & 530 & 63 & 250 & 110 \\
2014 & 547 & 105 & 250 & 113 \\
2015 & 552 & 114 & 250 & 81 \\
2016 & 700 & 183 & 255 & 160 \\
\hline
\end{tabular}

Source: MINFOF, 2016.

\subsection{Current Situation of Community Forests}

The first community forest was attributed to adjacent communities in 1997. In 2016, MINFOF statistics indicated that:

1. 683 applications for the attribution of community forest 
was registered from 1997 to date with a surface area of $2,191,385$ hectares of forest.

2. 193 community forests acquired temporal management convention giving a surface area of 825,524.5 hectares.

3. 274 community forests acquired final convention with a surface area of 940,205.9 hectares.

4. 182 active community forests has an Annual Exploitation Certificate (AEC) with an area of 28,272.5 hectares of forest.

It can be observed from the analysis that the demands for attribution of community forest, the number of temporal convention and final convention increased from 2010. Out of the 467 potentially exploitable community forests, only 182 has an annual exploitation certificate giving a 35 percent rate of forest attributed. The volume of wood attributed to community forests between 2010 and 2014 varies between 120,000 and $150,000 \mathrm{~m}^{3}$ while the average yearly volume exploited is $20,000 \mathrm{~m}^{3}$ (table 2). The average annual gap remains at $110,000 \mathrm{~m}^{3}$. The reasons for this increase in gap is due to selective exploitation of species by community forest, the late application for the annual exploitation certificate and the weak exploitation capacities of most community forest linked to lack of finance. Wood sold in the domestic market coming directly from sawing operations in non-permanent forest domain was estimated to be about $662,000 \mathrm{~m}^{3}$. This resulted to an annual average contribution rate of about $3 \%$ for the internal market [20].

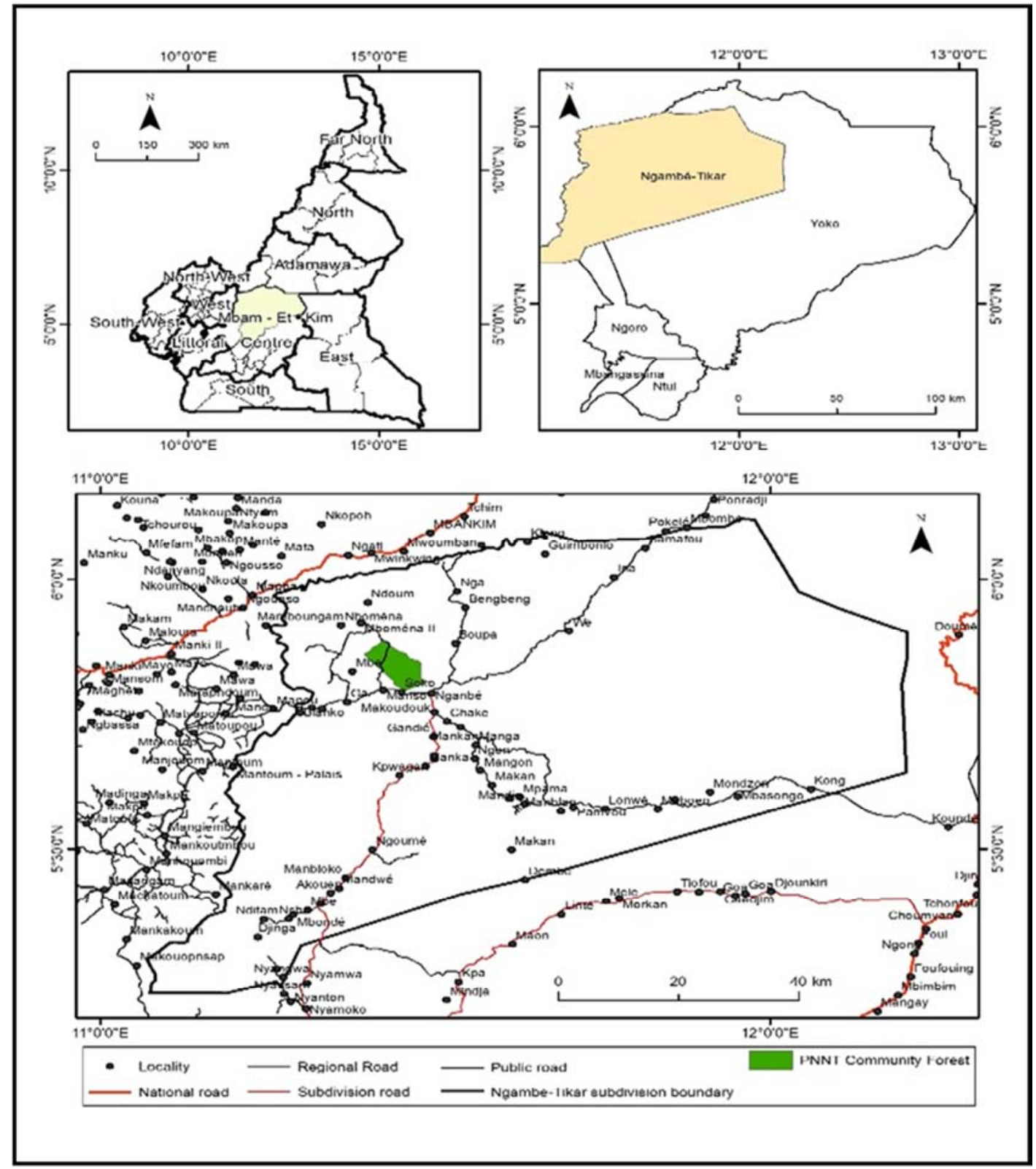

Source: Interactive Forest Atlas, 2016.

Figure 1. Location of study area (a) the Ngambe-Tikar in Cameroon, (b) Ngambe-Tikar in the Mbam and Kim division (c) PNNT community forest in NgambeTikar sub-division. 
Table 2. Attributed wood volume to community forest between 2010 and 2014 .

\begin{tabular}{lll}
\hline Year & Authorized logging volume & Logging volume exploited \\
\hline 2010 & 18000 & 140000 \\
2011 & 30000 & 146000 \\
2012 & 10000 & 146500 \\
2013 & 17000 & 120000 \\
2014 & 35000 & 120000 \\
\hline
\end{tabular}

Source: MINFOF, 2016.

\section{Method}

\subsection{Location of Study Area}

PNNT community forest was created on the $26^{\text {th }}$ June 2002 with surface area of 5000 ha. It is located in the NgambeTikar Sub-division of Mbam and Kim division, center region of Cameroon [22]. It is located between latitude $5^{\circ} 47^{\prime}$ to $5^{\circ} 62^{\prime}$ north of the Equator and longitude $11^{\circ} 29^{\prime}$ to $11^{\circ} 34^{\prime}$ east of the Greenwich Meridian (figure 1). The area has an average altitude of 825 meters. The average temperature is $27^{\circ} \mathrm{C}$ and rainfall ranges between $1500 \mathrm{~mm}$ to $2000 \mathrm{~mm}$ per year. Ngambe-Tikar experiences an equatorial climate of the Guinean type with two rainy seasons (from April to July and the second from September to November) and two dry seasons (November to March and mid-June to mid-August). The soil is clayey and the subsoil consists of rocks and granites [22].

\subsection{General Methodology}

This study focused on trends of land use changes and its influence on livelihoods in the PNNT community forest. It involved the use of mixed methods to complement each other consisting of primary and secondary data. Remote sensing technique and Geographical information system (GIS) were used to generate data on spatial and temporal changes in land use. This study employed moderate resolution Landsat images from Earth Explorer [23] to analyze land use change from 2001 to 2020 (19 years). The analysis was performed using the Landsat-7 Thematic Mapper (TM) for 2001 and 2011 and the Landsat-8, Operational Land Imager (OLI) for 2020. The random forest (RF) algorithm was further used for classification and ArcGIS 10.4 software for mapping. Primary data on livelihood activities was collected with the use of mainly questionnaires, focus group discussion and key informant interviews. Three Focused Group Discussions (FGD) were organized with women and men of adjacent communities involved in farming, collection of NTFPs and logging in the community forest. Key informant interviews were further used to collect complementary information about the community forest. This constituted mainly information about livelihood sources, achievements and challenges. In total, 65 respondents participated in the interview. The data collected through household questionnaire survey were descriptively analyzed using Excel and SPSS version 25.0.

\subsection{Image Acquisition and Pre-processing}

Three Landsat images were used in this study as follows: Landsat 7 Thematic Mapper (TM) images captured on 05 February 2001 and 16 January 2011 as well as Landsat 8 Operational Land Imager (OLI) images captured on $1^{\text {st }}$ January 2020 (Table 3). The images were downloaded from the Glovis websites [23].

Table 3. Data and sources used for the analysis of land use change in the study area.

\begin{tabular}{|c|c|c|c|c|c|c|c|c|}
\hline Satellite & Sensor & $\mu \mathrm{m}$ & Band & $\begin{array}{l}\text { Scene width } \\
(\mathrm{km})\end{array}$ & $\begin{array}{l}\text { Spatial } \\
\text { resolution }\end{array}$ & $\begin{array}{l}\text { Date of } \\
\text { acqiusition }\end{array}$ & Season & Source \\
\hline Landsat 7 & Thematic Mapper (TM) & $0.45-2.35$ & 7 & $170 \mathrm{~km} \times 183 \mathrm{~km}$ & $30 \mathrm{~m}$ & 05 February 2001 & Dry & http://glovis.usgs.gov/ \\
\hline Landsat 7 & Thematic Mapper (TM) & $0.45-2.35$ & 7 & $170 \mathrm{~km} \times 183 \mathrm{~km}$ & $30 \mathrm{~m}$ & 16 January 2011 & Dry & http://glovis.usgs.gov/ \\
\hline Landsat 8 & Operation al Land Imager (OLI) & $0.43-1.39$ & 11 & $170 \mathrm{~km} \times 183 \mathrm{~km}$ & $30 \mathrm{~m}$ & $1^{\text {st }}$ January 2020 & Dry & http://glovis.usgs.gov/ \\
\hline
\end{tabular}

Source: Authors' conception.

This time analyses of land use change in PNNT community forest require a proper selection and preparation to ensure the compatibility of the Landsat images. In this study, the images were selected from the same season (dry season) and with cloud cover not exceeding $10 \%$ with a spatial resolution of $30 \mathrm{~m}$.

\subsection{Classification Methods}

The supervised classification method by employing minimum distance algorithm was used in this study and land use map for each Landsat scene was generated. A supervised classification is the type of classification whereby the user collects samples of the land cover classes (training data) for different land cover classes and the image classification software determines each class by what it resembles most in the training signatures to perform the classification [2]. Postclassification processing was carried out and included recoding, majority filtering, clumping, elimination and mosaicking. This was to produce accurate change detection. The classified images were recorded into the four classes: Moist evergreen forest, degraded forest, savanna and bare soils. 


\section{Results}

\subsection{Land uses in the PNNT Community Forest}

Four main land uses identified within the PNNT community forest: Moist evergreen forest, degraded forest, savanna and bare soils. The moist evergreen forest constituted mainly the core area with almost no human intervention except hunting and collection of some Non-Timber Forest Products (NTFPs). The degradation of the moist forest area resulted to the degraded land use class. This area was characterised by forest exploitation at a local scale and the establishment of agroforestry like cocoa plantations. Degraded forest had very little canopy cover as compared to the moist evergreen forest. The savanna land use class was mostly characterized by cassava, cocoyam, plantain and cocoa farms, within which some forest trees were interspersed. When the moist evergreen forest is highly degraded, it give rise to the savanna. The bare soil made up the last class of land use in the PNNT community forest. It comprised of newly cleared area for agricultural extension, rocks, areas ravaged by natural and human induced bush fire. The area was characterised by traditional slash and burn methods of farming with a greater rate of deforestation (Table 4).

Table 4. Land use change in the PNNT community forest from 2001-2020.

\begin{tabular}{|c|c|c|c|c|c|c|c|c|c|}
\hline \multirow{3}{*}{ Land use type } & \multicolumn{6}{|c|}{ Area coverage per year } & \multicolumn{3}{|c|}{ Change in land use over the years } \\
\hline & \multicolumn{2}{|l|}{2001} & \multicolumn{2}{|l|}{2011} & \multicolumn{2}{|l|}{2020} & \multirow[b]{2}{*}{$\begin{array}{l}2001 \text { to } \\
2011 \text { (ha) }\end{array}$} & \multirow[b]{2}{*}{$\begin{array}{l}2011 \text { to } \\
2020 \text { (ha) }\end{array}$} & \multirow{2}{*}{$\begin{array}{l}2001 \text { to } \\
2020 \text { (ha) }\end{array}$} \\
\hline & Area (ha) & $\begin{array}{l}\text { Area ratio } \\
(\%)\end{array}$ & Area (ha) & $\begin{array}{l}\text { Area ratio } \\
(\%)\end{array}$ & Area (ha) & $\begin{array}{l}\text { Area ratio } \\
(\%)\end{array}$ & & & \\
\hline Moist evergreen forest & 2711.22 & 52.6 & 2542.58 & 49.3 & 2455.35 & 47.6 & -168.64 & -87.23 & -255.87 \\
\hline Degraded forest & 131.3 & 02.5 & 238.09 & 04.6 & 305.7 & 05.9 & 106.79 & 67.61 & 174.4 \\
\hline Savanna & 1919.28 & 37.2 & 1658.39 & 32.2 & 1124.91 & 21.8 & -260.89 & -533.48 & -794.37 \\
\hline Bare soils & 396.61 & 07.7 & 719.34 & 13.9 & 1272.45 & 24.7 & 322.73 & 553.11 & 875.84 \\
\hline
\end{tabular}

$(-)$ indicates decrease

Source: Landsat 7 and 8 classification (2001, 2011 \& 2020).

\subsection{Spatio-temporal Variation in the Trends of Land Use Change}

The spatial and temporal variations in land use change over the nineteen years in the PNNT community forest were analyzed using supervised classification method. The landuse classification maps produced for the study area in 2001, 2011 and 2020 are presented in figure 2. The statistics on surface area and percentage change of each land use type based on the classified images of the study area are further indicated. Classified maps of 2001, 2011 and 2020 produced from downloaded Landsat images from the Glovis websites [23] are shown in figure 2. The estimated land cover class and land cover changes per class are presented in table 4 .

\subsection{Trends of Land Use Cover Change in PNNT Community Forest}

Obtained results indicated that moist evergreen forest surface reduced from 2711.22 hectares in 2001 to 2542.58 hectares in 2011, a total change of 168.64 hectares (16.86 hectares per year). The area of the moist evergreen forest further reduced from 2542.58 hectares in 2011 to 2455.35 hectares in 2020, a change in land use cover of 87.64 hectares (9.69 hectares per annum). The findings indicated that 255.87 hectares of moist evergreen forest was lost in the PNNT community forest between 2001 and 2020 (average of 13.47 hectares per year). The area lost was converted to degraded forest or savanna.

Degraded forest on its part experienced a positive trend. The surface area of degraded forest substantially increased from $2 \%$ of the total land use (131.3 ha) in 2001 to $5 \%$ (238.09ha) in 2011. The surface area further increased to $6 \%$ (305.7ha) in 2020. The total surface area of degraded forest as indicated by the results from the classified maps increased by 174.4 hectares from 2001 to 2020 .

The results showed that the surface area covered by savanna in the community forest had a negative trend from 2001 to 2020 . The surface area reduced from 1919.28 hectares (37\%) in 2001 to 1658.39 hectares (32\%) in 2011. There was a significant loss in the surface area of savanna land use of 2602.89 hectares over ten years from 2001 to 2011. The surface area further dropped from 1658.39 hectares $(32 \%)$ in 2011 to 1124.91 hectares $(22 \%)$ in 2020 . In a whole the surface area covered by savanna in the PNNT reduced by 794.37 (37\% to 22\%) from 2001 to 2020 .

The land use having the most significant increase from 2001 to 2020 classification of landsat images was bare soils. Bare soils constituted mainly of areas newly cleared for agricultural extension, rocks, areas ravaged by natural and human induced bush fire. The area was also characterised by traditional slash and burn methods of farming. The area covered by bare soils increased and almost doubled from $8 \%$ (396.61 ha) in 2001 to $14 \%$ (719.34 ha) in 2011. Over a period of ten years the bare soils in the community forest drastically increased in size by 322.73 hectares $(6 \%)$. Increase in population influence in the adjacent communities further increased the surface area of bare soil from $14 \%$ (719.34 ha) in 2011 to $25 \%$ (1272.45ha) in 2020 . The findings revealed that the surface area covered by bare soil in PNNT experienced the highest rate of increase from 2001 to 2020. The results showed that the surface area increased from 396.61 hectares in 2001 to 1272.45 hectares in 2020; a global increase in area of 875.84 hectares (Table 4). 


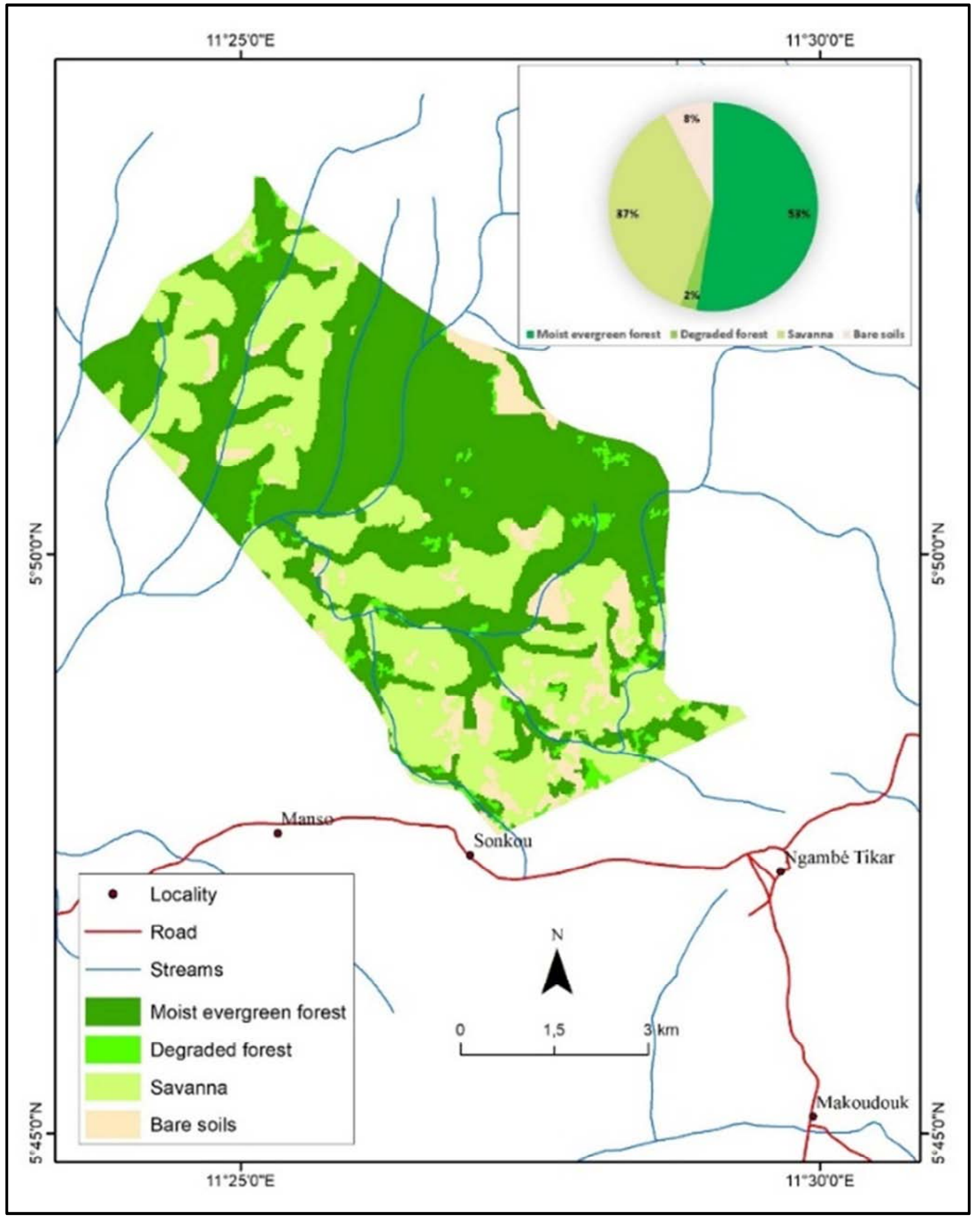




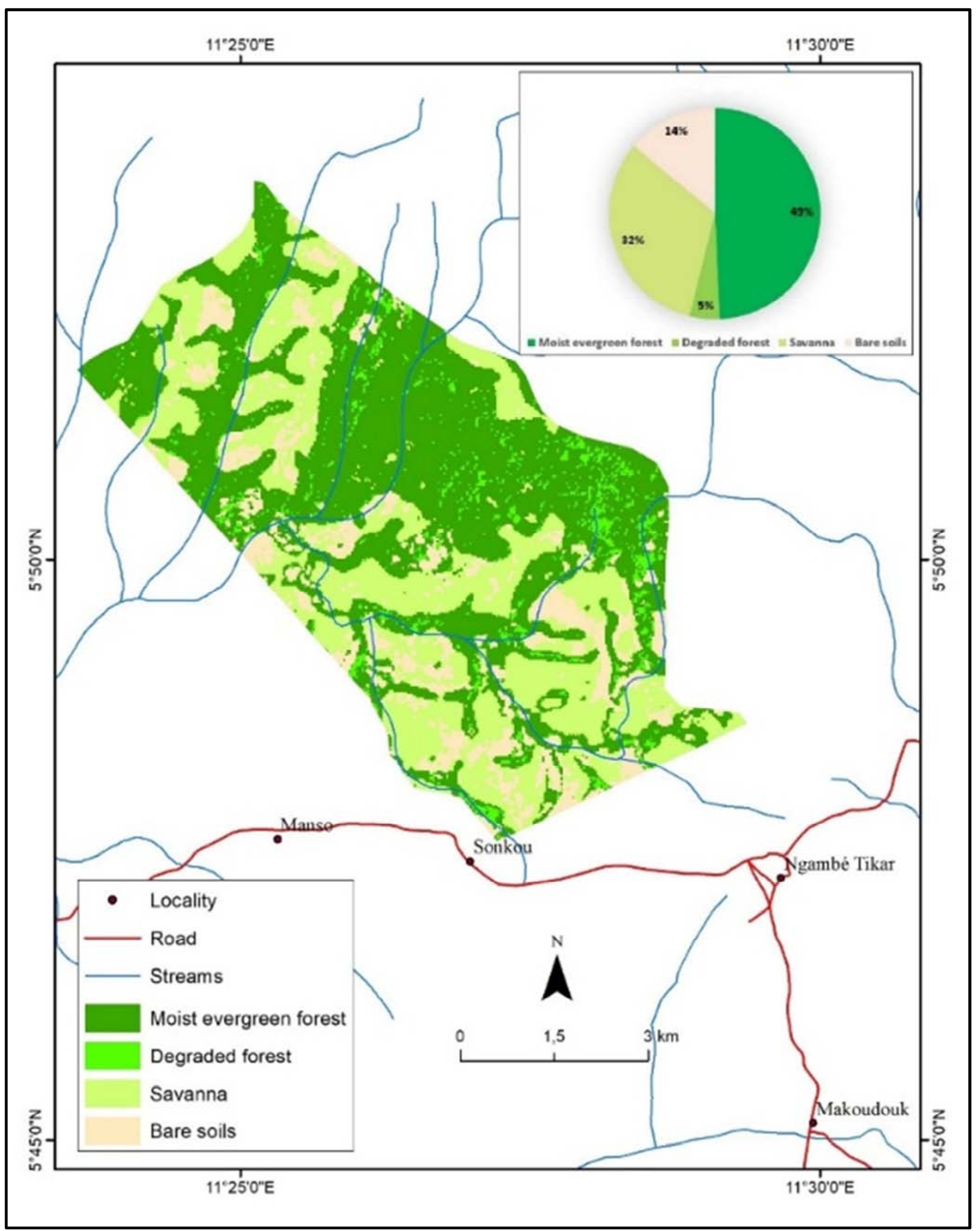




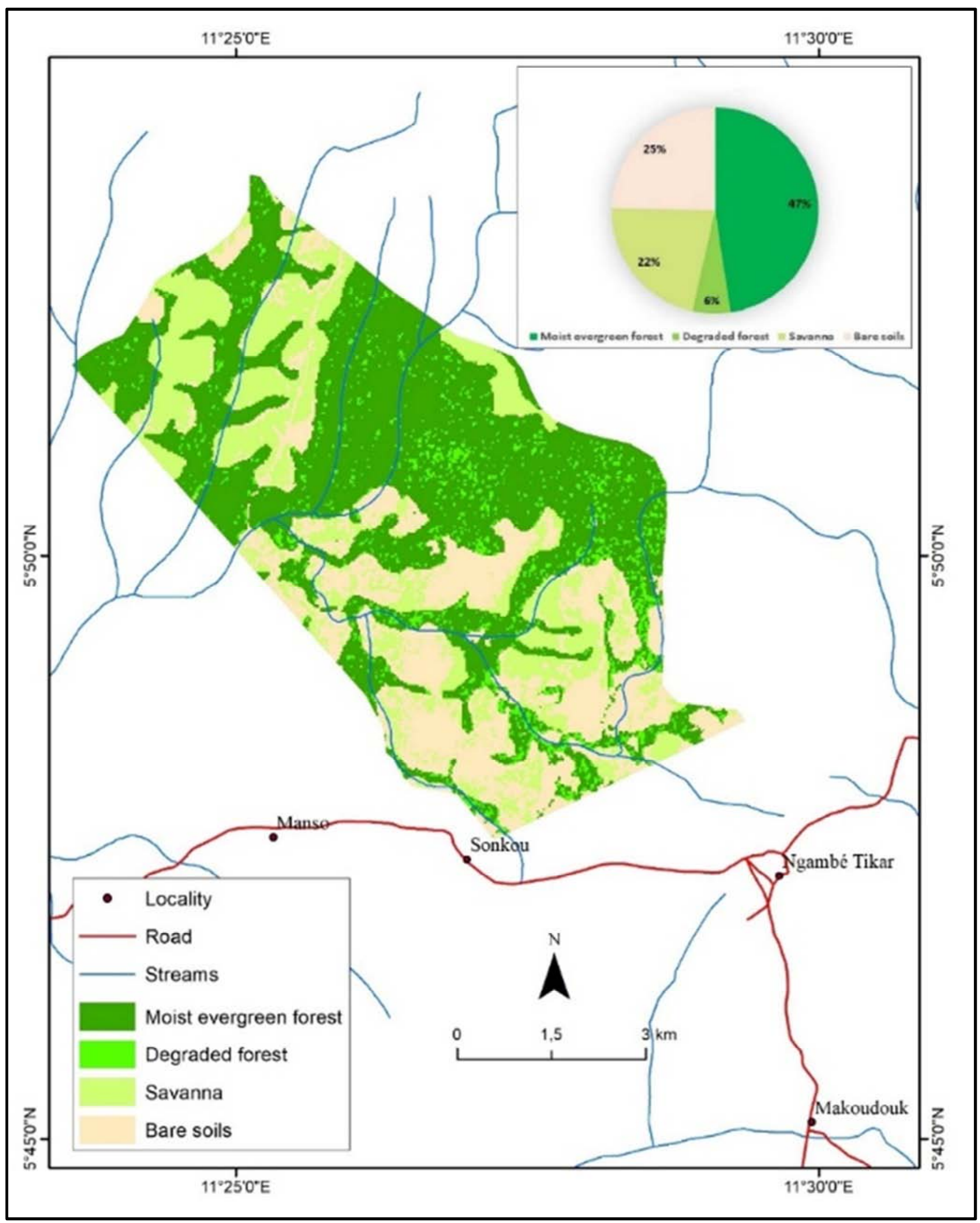

Source: Landsat 7 and 8, 2001, 2011 and 2020 images.

Figure 2. Land use map of PNNT community forest: (A) Land use map of PNNT community forest in 2001; (B) Land use map of PNNT community forest in 2011; and (C) Land use map of PNNT community forest in 2020. 


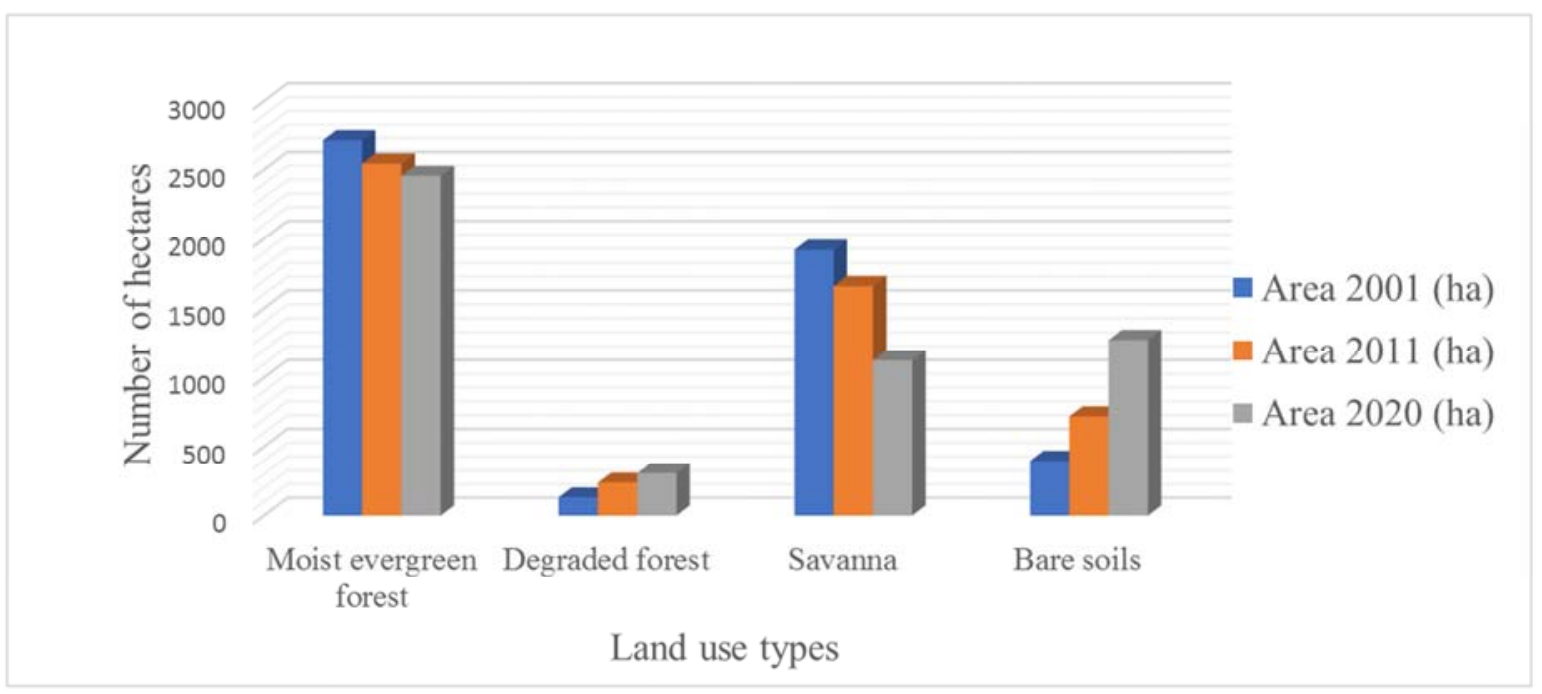

Source: Table 4 data.

Figure 3. Land use change in PNNT community forest.

\subsection{Livelihood Activities in PNNT Community Forest}

Population living in forest areas in Cameroon to a greater extent depend on forest resources for their livelihoods. The forest represents a kind of huge free "supermarket" providing food, medicines, construction and equipment materials, as well as ceremonial elements [24]. Their standard of living therefore closely depends on the quality of the forest [25]. All households in PNNT community forest area practice subsistence agriculture (men, women and youth); crops are cultivated mainly in individual fields. Main crops cultivated include: maize, cassava, plantain and cocoyam destined for consumption and sale. The main cash crop in the study area is cocoa. In addition to agriculture, there is also the involvement of women and men in the collection of nontimber forest products such as njansang and bush mango. Most of the collection of non-timber forest products is done
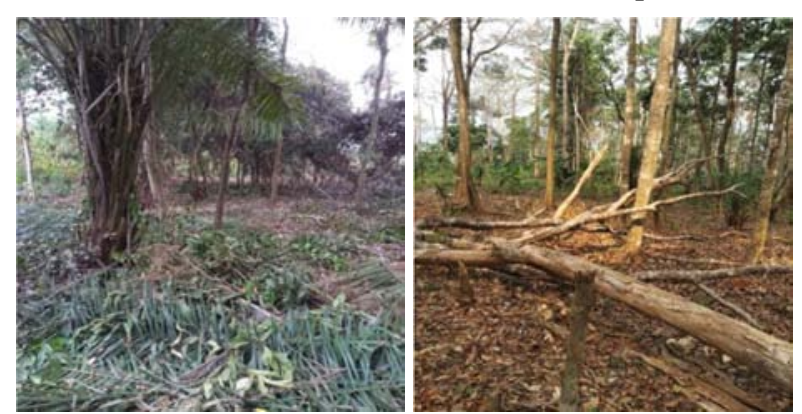

by women, but there are also some men and children who collect it. Globally, about 200 ha of annual crops (the most dominant is maize), 40 ha of mixed cropping (cocoa and plantain) and 5 ha of irrigated farm existed in the PNNT community forest.

Findings through field observations revealed that the continuous increase and expansion of human activities in the search for livelihood improvements have triggered the change in land use within the community forest from 2001 to 2020. The intensification of human activities seeking to ensure food supply and to improve the income of the growing population is the major proximate driver of land use change [26]. The results from household survey showed that more than $85 \%$ of the population carried out expansion in human agriculture and other livelihood activities, a key driver to land use change in the PNNT (figure 3).

Source: Field survey, 2020.

Figure 4. Agricultural expansion in the PNNT community forest: (A) a farm land cleared and burnt; (B) a newly cleared piece of land for agricultural expansion in PNNT; (C) full grown cocoa farm in PNNT; and (D) a mixed crop land in the PNNT.

The results further revealed that the exploitation of timber species at a small scale is one of the factors behind the change in land use. The PNNT community forest is reach in many timber valuable timber species (table 5). Villagers exploit the timber species for domestic markets of NgamberTikar, Bafia and in the city of Yaounde.
Table 5. Timber species in PNNT Community Forest.

\begin{tabular}{llll}
\hline No & Species & No & Species \\
\hline 1 & White Acajou & 17 & Emien \\
2 & Red Acajou & 18 & Eyong \\
3 & Aiele & 19 & Frake \\
\hline
\end{tabular}




\begin{tabular}{llll}
\hline No & Species & No & Species \\
\hline 4 & Alep & 20 & Fromager \\
5 & Aningre-A & 21 & Illomba \\
6 & Aningre-R & 22 & Kossipo \\
7 & Ayos & 23 & Kotibe \\
8 & Bahia & 24 & Lotofa \\
9 & Bibolo afum & 25 & Mutondo \\
10 & Bilinga & 26 & Niove \\
11 & Bongo & 27 & Onzambili \\
12 & Bosse-clair & 28 & Red padouk \\
13 & Dabema & 29 & White padouk \\
14 & Dibetou & 30 & Sapelli \\
15 & White doussie & 31 & Sipo \\
16 & Red doussie & 32 & Tali \\
\hline
\end{tabular}

Source: Simple management plan, 2015.

An inventory of fauna species carried out through a semistructured interview was carried out with hunters and fishermen to get both the land and aquatic animals in the PNNT community forest (table 6).

Table 6. Inventory of animal species found within PNNT community forest.

\begin{tabular}{lll}
\hline Local name & $\begin{array}{l}\text { Name in the } \\
\text { dialet }\end{array}$ & $\begin{array}{l}\text { Index of } \\
\text { abundance }\end{array}$ \\
\hline Buffle & Nzou & ++ \\
Bush pig & Nguene-nguene & ++ \\
Sanglier & Ngah & +++ \\
Antelop & Nzana & ++ \\
Gazelle & Mbongbong & ++ \\
Cynocephali & Doudou & +++ \\
Python & Lesse & ++ \\
Cephalophes a dos jeune & & +++ \\
Cephalophes a bandes dorsales noire & & +++ \\
Cephalophes bleus & & ++ \\
Ecureuils divers & & +++ \\
Herissons & & +++ \\
\hline
\end{tabular}

\begin{tabular}{lll}
\hline Local name & $\begin{array}{l}\text { Name in the } \\
\text { dialet }\end{array}$ & $\begin{array}{l}\text { Index of } \\
\text { abundance }\end{array}$ \\
\hline Pangolins & ++ \\
Genettes & ++ \\
Civettes & +++ \\
Moustac & + \\
Rat de gambi & ++ \\
Cob & ++ \\
Varan & ++ \\
Vipers and other snakes & ++ \\
Tortoise & ++ \\
Pintades & +++ \\
Perdix and other birds & +++ \\
Eagle & + \\
\hline
\end{tabular}

+++ : very abundant ++ : Abundant + : Rare.

Source: Simple management plan, 2015.

About $80 \%$ of the people in the developing world depend on Non-Wood Forest Products (NWFPs) for their primary health and nutritional needs and/or in terms of meeting their subsistence consumption and income needs. In many countries NWFPs form an important component of forest products exports $[27,25]$. The survey of household through interviews, questionnaires and information from secondary data indicated that there are many NTFPs present in the community forest used by the local people for livelihood improvements. Principal products include: Anonidium mannii, Gambeeya lacourtiana, Garcinia kola, Irvingia gabonensis, Ricinodendron heudelotii, Tetrapleura tetrptera, Afrostyrax lepidophyllus and Fagara macrophyla. These NTFPs are used as spices, commercialized and cosmetic purposes (table 7).

Table 7. Main Non-timber forest products in PNNT community forest.

\begin{tabular}{llll}
\hline Scientific name & Part of product used & Frequency & Observation \\
\hline Anonidium mannii & Fruit & Rare & Comestible \\
Gambeeya lacourtiana & bark & Abundant & Comestible \\
Garcinia kola & Grains and bark & Rare & Comestible, commercialised, used to ferment palm wine, species under-exploited \\
Irvingia gabonensis & Fruit and amande & Rare & Comestible, spices, commercialised \\
Ricinodendron heudelotii & Amande & Abundant & Spices, commercialised \\
Tetrapleura tetrptera & Fruit & Abundant & Spices, commercialised \\
Afrostyrax lepidophyllus & Bark & Rare & Spices \\
Fagara macrophyla & bark & Rare & Commercialised \\
\hline
\end{tabular}

Source: Simple management plan, 2015.

\section{Discussion}

Land use in forest varied by cover class and physiographic zone [28]. The major land uses identified in the PNNT community forest were moist evergreen forest, degraded forest, savanna and bare soil. The classified surface map of the PNNT community forest area ratio showed that moist evergreen forest, degraded forest, savanna and bare soils were the dominant land cover types. The moist evergreen forest covered $52.6 \%$, savanna $37.2 \%$, bare soils $7.7 \%$ and degraded forest $2.5 \%$ in 2001 . From 2001 to 2011 the moist evergreen forest and savanna witnessed a reduction in surface area by $3.3 \%$ and $5 \%$ respectively while degraded forest and bare soil experience a significant increase in surface area by $2.1 \%$ and $6.2 \%$ respectively. This was a similar scenario from 2011 to 2020 as moist evergreen forest and savanna surface area reduced by $1.7 \%$ and $10.4 \%$ respectively while degraded forest and bare soil experience an increased in surface by $1.3 \%$ and $10.8 \%$ respectively of the total land cover types. In a whole, from 2001 to 2020 the surface area of moist evergreen forest reduced by $5 \%$, savanna by $15.4 \%$ while degraded forest increased by $3.4 \%$ and bare soil also increased by $17 \%$ of the total land cover (Table 4 ).

The main reasons behind the land use and land cover changes included rapid population growth, rural-to-urban migration, reclassification of rural areas as urban areas, lack 
of valuation of ecological services, poverty, ignorance of biophysical limitations, and use of ecologically incompatible technologies [29]. The moist evergreen forest has been converted to degraded forest and savanna through the exploitation of timber by the population from various villages found around the PNNT. The major timber species (Table 5) are exploited either for personal use in the construction of houses and other household furnitures or for sale in the major urban centers of the central region like Bafia and Yaounde. This is exacerbated by the creation and expansion of cocoa farms in the area by the growing population. This reality on the field was consistent with the trends of conflicts between food production and conservation objectives which have been predicted to increase $[30,5]$. The growth in the population due to natural increase and migration has resulted to scarcity of land, thus encroachment into PNNT community forest. Findings from the field survey further revealed that village heads (chiefs) are selling hectares of land in the community forest for agricultural expansion. The degraded savanna land use area are converted to bare soil through slash and burn methods of farming. The survey revealed that, the continuous increase in the surface area of bare soil by $17 \%$ from 2001 to 2020 was due to poor farming methods that provoked rapid degradation of the land. Similar studies in south-central Senegal have found that increased demographic pressures have resulted in an increase in cultivated and settlement lands at the expense of other land covers [3, 2].

In terms of livelihood activities in the PNNT community forest, agriculture involving the cultivation of food crops such as maize, cocoyam, cassava and plantains as well as cash crop such as cocoa dominated in the study area. Results further revealed that the populations are involved in the exploitation of timber and the harvesting of major non-timber forest products in the community forest for family consumption and for sale. These human activities contributed at different decree to land use change in the PNNT. In addition, a study in the Kenya [2] have shown that human activities like agriculture, free livestock grazing, wood extraction for fuel wood and charcoal-making as well as wood for domestic use and settlement expansion were observed to adversely cause changes in land use in the Kilombero Valley Floodplain, Southeastern Tanzania. Similar findings [25] in the Bamboko Forest Reserve in Cameroon indicated that unsustainable harvesting methods and excessive harvesting of NTFPs have resulted in a fall in quantity collected and degradation of the forest reserve. Field survey revealed a similar scenario in the PNNT where human activities was noticed to be the major force behind land use change between 2001 and 2020 .

\section{Conclusion}

The objectives of this study was to assess land use change and livelihood activities in PNNT community forest from 2001 to 2020 . The results of the study clearly revealed that PNNT has experienced significant changes in land use over 19 years. There was a substantial reduction in the surface area of moist evergreen forest and savanna land uses in the PNNT. The results showed a significant increase in the surface area of degraded forest and bare soil in the study area. The search for livelihoods resulted in agricultural expansion, increased logging and harvesting of non-timber forest products, thereby provoking a change in land use change in the community forest. To ensure sustainable development in the PNNT, the follow up of the ongoing land use change over long periods is very pertinent and the implementation of better policies and strategies are imperative in the area.

\section{Author Contributions}

Nghobuoche Frankline designed the study, analyzed the data, and prepared the manuscript with contributions from the co-authors who took part in the conceptualization of ideas, the methodology, fieldwork and the review of the manuscript.

\section{Funding}

This research was funded by the Regional Research Center for Sustainable Development (RReCSuD) grant number (2020RReCSuD001AB).

\section{Conflicts of Interest}

The authors declare that they have no competing interests.

\section{Acknowledgements}

Nghobuoche Frankline is thankful to the Regional Research Center for Sustainable Development (RReCSuD) for providing funds to carry out this research. Sincere thanks to all the authors for their endless support in carrying out the research and developing the manuscript.

\section{References}

[1] Rowcroft, P. (2005). Gaining Ground: The Socio-Economic Driving Forces Behind Decisions Regarding Land Use and Land Use Change; An Overview, Working Paper 16: Vientiane, Loas, 2005.

[2] Nangware, K. M., Lianxi S. and Lyimo, J (2019). Land Use Change Trends and Their Driving Forces in the Kilombero Valley Floodplain, Southeastern Tanzania. Sustainability 2019, 11, 505; $\quad$ doi: $\quad 10.3390 /$ su11020505. www.mdpi.com/journal/sustainability.

[3] Wood, E. C.; Tappan, G. G.; Hadj, A. 2004. Understanding the drivers of agricultural land use change in central Senegal. J. Arid Environ. 2004, 59, 565-582.

[4] Lambin, E. F., Turner, B. L., Geist, H. J., Agbola, S. B., Angelsen, A., Bruce, J. W.,... Xu, Y. (2001). The causes of land-use and land-cover change: Moving beyond the myths. Global Environmental Change, 11 (4), 261-269. 
[5] Ambo, F. B., Tabi, T. P., Bakia, M. A. \& Che, C. A. 2019. Patterns of land-use change and current vegetation status in peri-urban forest reserves: the case of the Barombi Mbo Forest Reserve, Cameroon, Geology, Ecology, and Landscapes, 3: 2, 104-113, DOI: 10.1080/24749508.2018.1508981.

[6] Carlson, K. M., Curran, L. M., Ratnasari, D., Pittman, A. M., Soares-Filho, B. S., Asner, G. P. and Rodrigues, H. O. (2012). Committed carbon emissions, deforestation, and community land conversion from oil palm plantation expansion in West Kalimantan, Indonesia. Proceedings of the National Academy of Sciences, 109 (19), 7559-7564.

[7] Wickramagamage, P. 1998. Large-scale deforestation for plantation agriculture in the hill country of Sri Lanka and its impacts. Hydrological Processes, 12 (13-14), 2015-2028.

[8] Kenfack Essougong, U. P., D. Foundjem-Tita, and P. A. Minang. 2019. Addressing equity in community forestry: lessons from 20 years of implementation in Cameroon. Ecology and Society 24 (1): 9. https://doi.org/10.5751/ES10656-240109.

[9] Chao, S. 2012. Forest peoples: numbers across the world. Forest Peoples Programme, Moreton-in-Marsh, UK. [online] URL:

http://www.forestpeoples.org/sites/fpp/files/publication/2012/ 05/forestpeoples-numbers-across-world-final_0.pdf.

[10] Food and Agriculture Organization of the United Nations (FAO). 2014. State of the world's forests: enhancing the socioeconomic benefits from forests. FAO, Rome, Italy. http://www.fao.org/3/ai3710e. pdf.

[11] Arnolds, J. E. M. 2001. Forests and people: 25 years of community forestry. Food and Agriculture Organization, Rome, Italy. [online] URL: http://www.fao.org/docrep/012/y2661e/y2661e00.htm.

[12] Ribot, J. C. 2002. Democratic decentralization of natural resources: institutionalizing popular participation. World Resources Institute, Washington, D. C., USA. [online] URL: https://vtechworks.lib.vt.edu/bitstream/handle/10919/65426/3 61_ddnr_full_revised.pdf ?sequence $=1$.

[13] Bernard, F., and P. Minang. 2019. Community forestry and REDD+ in Cameroon: what future? Ecology and Society 24 (1): 14. https://doi.org/10.5751/ES-10708-240114.

[14] Beauchamp, E., and V. Ingram. 2011. Impacts of community forests on livelihoods in Cameroon: lessons from two case studies. International Forestry Review 13 (4): 389-403. https://doi.org/10.1505/146554811798811371.

[15] Lescuyer, G. 2010. Importance économique des produits forestiers non ligneux dans quelques villages du Sud Cameroun. Bois et Forêts des Tropiques 304 (2): 15-24. http://dx.doi.org/10.19182/bft2010.304.a20442.

[16] Awono, A., R. Atyi Eba'a, D. Foundjem-Tita, and P. Levang. 2016. Vegetal non-timber forest products in Cameroon, contribution to the national economy. International Forestry $\begin{array}{llll}\text { Review } & 18 & \text { (1): }\end{array}$ http://dx.doi.org/10.1505/146554816819683708.

[17] Rights and Resources Initiative. 2015. Who owns the world's land? A global baseline of formally recognized indigenous and community land rights. Rights and Resources Initiative, Washington, D. C., USA. [online] URL: https://rightsandresources.org/wpcontent/uploads/GlobalBaseline_web.pdf.

[18] Akoa Akoa, R. Jr. 2007. Economic analysis of community forest projects in Cameroon. Thesis. Georg-August University of Goettingen, Goettingen, Germany. [online] URL:

https://agritrop.cirad.fr/550164/1/document_550164.pdf.

[19] Harley, R., M. Riddell, and S. N. Ndobe. 2012. REDD+ beyond carbon: insights from a community payments for ecosystem services project in Cameroon. Project Paper 2. Bioclimate Researchand Development, Edinburgh, UK. [online] URL: http://theredddesk.org/sites/default/files/resources/pdf/2012/re dd_beyond_carbon_community_pes_paper_2012.pdf.

[20] Fomou, G., Vandenhaute, M., and Feujio, D. (2017). Légalité et traçabilité des bois des forets communautaires de HautNyong (Cameroon). FAO \& SAILD. 54pp.

[21] MINFOF, 2009. Manuel des procédures d'attribution et des nomes de gestion des forets communautaires. MINFOF, Yaoundé, Cameroun, 64pp.

[22] Program Naional de Developpement Participatif (PNDP), 2013. Municipal development plan of Ngambe-Tikar, PNDP/CAFER, November 2013, 167pp.

[23] websites http://glovis.usgs.gov/.

[24] Djeukam, R., Gerber J. F. and Veuthey S. 2012. Forestry and Communities in Cameroon Robinson. Centre for Environment and Development (CED), and (ICTA-UAB). Yaoundé, Cameroon 30pp.

[25] Nghobuoche, F. 2015. The exploitation of non-timber forest products for local livelihood in the Bamboko Forest Reserve, South West Region of Cameroon. Masters Dissertation, University of Yaounde I. 156pp.

[26] Müller, D.; Zeller, M. 2004. Agricultural Intensification, Population Growth and Forest Cover Change: Evidence from Spatially Explicit Land Use Modeling in the Central Highlands of Vietnam; Springer: Berlin/Heidelberg, Germany, 2004; pp. 495-519.

[27] Agustino, S.; Mataya, B., Senelwa, K., and Achigan-dako, G. E. (2011): Non-wood Forest Products and Service for socioeconomic development. A Compendium for Technical and Professional Forestry Education. The African Forest Forum, Nairobi, Kenya. 219pp.

[28] Coulston, J. W., Gregory, A., Reams, A. and Brewer, C. K. 2014. An analysis of forest land use, forest land cover and change at policy-relevant scales. An International Journal of Forest Research. Forestry 2014; 87, 267-276, doi: 10.1093/forestry/cpt056.

[29] Mallupattu, P. K. and Sreenivasula, J. R. 2013. Analysis of Land Use/Land Cover Changes Using Remote Sensing Data and GIS at an Urban Area, Tirupati, India. Hindawi Publishing Corporation The ScientificWorld Journal Volume 2013, Article ID 268623, 66 pp http://dx.doi.org/10.1155/2013/268623.

[30] Laurance, W. F., Sayer, J., \& Cassman, K. G. 2014. Agricultural expansion and its impacts on tropical nature. Trends in Ecology and Evolution, 29 (2), 107-116. 